\title{
IV.
}

\section{Intercultural Perception}




\title{
On natural law in Islam. Some preliminary remarks
}

\author{
Remi Brague
}

Let me begin with a captatio benevolentiae that must be neither short nor merely rhetorical in nature.

My topic is not an easy one for two reasons. The first reason is that I must warn you against myself: I am in no way a specialist on Islam, let alone on Islamic Law. To be sure, some years ago, I wrote a book on the idea of divine law in Judaism, Christianity and Islam that was published in 2005. It contains some pages on the link between the ideas of law and nature in Islamic thought ${ }^{1}$. The present paper will mainly reproduce their content. Yet, I have not been giving a great deal of my time to such issues ever since.

The second reason that accounts for the difficulty of my topic is that it might be a leprechaun. There probably is no such thing as a natural law in Islam. Some authors bluntly make this point. This is the case of Patricia Crone, in her bulky history of medieval political thought in Islam ${ }^{2}$. Therefore, I might indulge in some shadow-boxing.

\section{The silence of recent scholarship}

As for the first reason, I wanted to somehow keep up to date. In order to do that, I had a look at more recent work and skipped through two books, both published in 2009, one in German by Matthias Rohe (University of Erlangen-Nuremberg) and the synthesis in English by Wael B. Hallaq (McGill University, Montreal) ${ }^{3}$.

As for the second reason, I was surprised to observe that in those books that are meant to present us with an overview of Islamic Law, the items "natural law", and even "nature" are conspicuously absent from the index of ideas. Some other words are absent, too, such as Conscience / Gewissen.

There are two recent works that claim to specifically cope with the topic of natural law in Islam. I could not find the book of an author by the name of Abu 'l-Fadl Ezzati' But I could lay my fingers on a most recent book, the revised form of a $\mathrm{PhD}$ written by a gentleman by the name of Anver M. Emon, which deals most explicitly with this topic and was published last year ${ }^{5}$. Now, what is especially striking is that, most sur-

${ }^{1}$ R. Brague, The Law of God, tr. L. Cochrane, Chicago: Chicago University Press 2005 [here: Law]

2 P. Crone, God's Rule: Government and Islam, New York, Columbia University Press, also as: Medieval Islamic Political Thought, Edinburg: Edinburg University Press 2004, 263-264.

3 M. Rohe, Islamisches Recht (Munich: Beck 2009); Wael B. Hallaq, Shari'a. Theory, Practice, Transformations, Cambridge: Cambridge University Press 2009; Id., Introduction to Islamic Law, Cambridge: Cambridge University Press 2009.

4 A. Ezzati, Islam and Natural Law, London: ICA Press 2002.

5 A. M. Emon, Islamic Natural Law Theories, Oxford; Oxford University Press 2010. 
prisingly, the word "nature" is absent from the index. There are two entries that roughly correspond to what could have been an entry on "Nature".

But the first one, "Naturalistic fallacy", sends us to a passage that deals with the way in which some Islamic thinkers rebuked the idea according to which we can elicit norms from what happens among things. Whether the idea was actually supported by some people or whether it was, as this often happens in Islamic heresiography, put forward only in order to be refuted, need not bother us here.

The second entry is concealed under the Arabic word $t a b$ ', which actually means something like "nature". Now, it does not occur as such, but only in the formula Ahl al$t a b$ '. This is a category to be found in the work of Ibn 'Aqīl, a conservative collector and commentator of hadiths ("traditionist") of the $11^{\text {th }}$ Century. The phrase is translated as "the People of natural dispositions". Those people are supposed to have contended that the right and the wrong can be distinguished on the basis of the individual's natural dispositions, without recourse to God's revealed word'6. Again, we may ask whether this group was more that a mere logical possibility, a mere scarecrow. In Emon's book, the English word "nature" does occur, but, unless I am very much mistaken, never as the translation of the Arabic word $\operatorname{tabĭ}^{\prime} a$. Nature designates what the author calls "natural teleology".

There are other strange things in Emon's book. For instance, the Arabic word maqassid, which means the intentions of the laws, is present in the Index, but not in the text.

The bulk of the book deals less with nature than with reason. It emphasizes the rational character of some rulings, the way in which some legal scholars looked for the reasons ('illa) that underlie the rulings, in particular the advantage (maslaha) of people. But the concept of a natural law is hardly there.

How is this to be accounted for?

\section{Islam as unknown}

The first thing that deserves to be brought to mind is the nature of Islam. It is not the case that we have of Islam an adequate understanding such as to enable us directly to ask what natural law in Islam is. The very word Islam is ambiguous. Let me distinguish three basic meanings. Islam designates as well:

(1) what I will call, at least provisionally and for want of anything better, a "religion", a stance of wholehearted surrender (in Arabic: islām) to the will of God;

(2) a historic and geographic fact. A culture that stretches in space from Mauretania to Indonesia, from the $7^{\text {th }}$ Century to our present day; and finally

(3) a group of people living today in countries in which Islamic religion is dominant and that were the stage on which Islamic culture took place.

The trouble with Islam is not so much our knowledge of it. To be sure, knowledge of Islam among Western people is not as satisfactory as it should be. This depends very

6 Ibn Aqil, Al-Wadih fi usul al-figh, ed. G. Maqdisi, Beirut: Steiner 1996, t. I, p. 9. 
much on the kind of people: uneducated or educated, not to mention learned orientalists. Legends about Muhammad abounded in Medieval Europe, and they were for the most part rather libel than history. Yet, alongside of it, there exists a long tradition of oriental studies, beginning as early as the $12^{\text {th }}$ Century with Peter the Venerable's enterprise of having translated into Latin the Quran and some basic documents about Muhammad and his message ${ }^{7}$. It never was interrupted and produced a bevy of great scholars that have enlarged our knowledge.

The real trouble is double. It lies first in the thing itself, then in our perception of it. The points I am about to make have no direct bearing on our topic. Yet, I will substantiate them by looking at examples that I picked because of their relevance for the said topic.

\section{Facts}

First, the circumstances which brought about the birth and spreading of Islam are far from being clear and our knowledge about them scanty. To be sure, we possess an official history of sorts, which is to be found first and foremost in Ibn Ishaq's Sira, some sort of life of Muhammad that Ibn Hisham claims to have edited and published. We possess a reliable English translation, with notes and indices ${ }^{8}$. This book, together with some other ones like the Book of the Conquests (Kitāb al-Maġa $z$ i) of al-Waqidi ${ }^{9}$, remains the basis of almost every biography of Muhammad and of the rise of Islam.

Now, those books were written about a century and a half after the facts they purport to relate, in a geographic and above all social and cultural surrounding that differs widely from the framework in which the reported events are supposed to have taken place.

If we decide, for reasons of method, to rely exclusively on sources that are dated, i.e. monuments, inscriptions, coins, documents of legal and administrative nature, reports from non-Muslim authors living in the Islamic area, etc., we get a somehow different picture. For instance, we possess a report of a discussion held in the early years of the $8^{\text {th }}$ century between the emir of the "Hagarenes" and a Christian patriarch about the legal authorities of both sides. Curiously, there is no allusion whatsoever to the existence of a new religion, of a new book, let alone of a new prophet ${ }^{10}$. Facts of this kind have led some scholars to adopt a very critical stance towards the traditional account.

Be that as it may, it is interesting that the first hard fact that we can grasp in the late $7^{\text {th }}$ and early $8^{\text {th }}$ century is not religious, but military, political and-what is espe-

${ }^{7}$ See P. Kritzeck, Peter the Venerable and Islam, Princeton: Princeton University Press, 1964.

8 A. Guillaume, The Life of Muhammad. A Translation of Ibn Ishaq's Sirat Rasul Allah, Oxford 1955.

9 The Life of Muhammad. Al-Waqidi's Kitab al-Maghazi, tr. R. Faizer, Routledge 2010 [non vidi].

${ }^{10} \mathrm{~F}$. Nau, Un colloque du patriarche Jean avec l'émir des Agaréens et faits divers des années 712 à 716 [...], in: Journal Asiatique, XI-5, 1915, p. 225-27.9. 
cially relevant for us-legal in nature. From the mid- $7^{\text {th }}$ century, Arabic tribes obviously exert state power in areas that used to be controlled by "Roman" power, i.e. the Eastern Empire, which we call "Byzantine" from its capital Constantinople. A meaningful example is the fact that the earliest dated document that we possess is a legal document, a receipt written on papyrus in 643 in the Greek and Arabic languages, bearing witness that taxes were paid to the local authorities by an Egyptian fellah ${ }^{11}$.

The military and political situation was the occupation of vast territories, peopled by a motley mixture of peoples, by a military caste living in the country in the same way as every foreign ruling class had done in the Middle East, from the Persians to the Hellenistic Greeks after the conquests of Alexander the Great and finally to the Romans, first pagans, then converted to Christianity.

This can help us better to understand why Islam emphasizes so much the rules of conduct: an aristocracy has to stick to its own habits and mores in order to distinguish itself from its subjects. Having precise rules to abide by was not only required for people to live peacefully with each other, which happens in each and every form of society. What was at stake was the very identity of a group that wanted to stay together and to go on wielding power over the rest. For this reason, they needed a strong legitimating principle: rules of behaviour had to stem from the highest source of authority, i.e. from God.

\section{Islam as unknown: ideas}

The second difficulty may be greater still. It is intellectual in nature. We are at great pains to look at Islam without our donning Western spectacles, less prosaically, without our foisting on it Western categories. They largely determine what we accept to take cognizance of and what our intellectual stomach simply cannot swallow.

Let me take as example Islamic rules of behaviour in everyday life, again because they are germane to our present topic. As is well known, Muslim males are expected to trim their moustache and let their beard grow; females are expected to cover their head and chest with a veil. In the face of such phenomena, Western people more often than not adopt the point of view of the tourist who looks at unusual and colourful habits with amazement and perhaps with a touch of contempt, but at the same time with some aesthetic pleasure. They think: that is just one more "queer thing that queer foreign people do". In the Scottish Highlands, gentlemen wear filibegs; French people feed almost exclusively on frogs and snails; in Islamic countries, ladies wear a headscarf, etc. All these practices are supposed to be on the same level, to belong to some sort of folklore. Western people simply cannot understand that, for many Muslims, this kind of dress code originates in God's explicitly formulated will: the male hairdo in an utterance of the Prophet, a so-called Hadith; the female head-gear in two verses of the Holy Book (XXIV, 31; XXXIII, 59).

11 Papyrus Erzherzog Rainer. Führer durch die Ausstellung, Vienna 1894, N. 558, p. 139 or A. Grohmann, From the World of Arabic Papyri, Cairo 1952, p. 113-115. 
Western people more or less easily accept that God can issue commands that are moral in nature, like the Ten Commands, the so-called Decalogue (Exodus, 20). On the other hand, they can hardly believe that God takes interest in the puniest details of our everyday life.

The very word "religion" that I used above as a first step, is misleading, because it is Eurocentric. Thrown into the bargain, this meaning is a recent one, not much older than the $19^{\text {th }}$ century. The medieval scholastic authors knew better, when they used the Latin word lex. St Thomas Aquinas, for instance, speaks of the lex Maurorum, meaning thereby Islam ${ }^{12}$. Theses authors meant by lex a full-fledged system of salvation, which could present itself under different guises: in Christianity, it took the shape of the biblical salvation history that developed in the two Covenants and culminated in Jesus Christ's death and Resurrection; in Islam, it became the system of rules which mankind has to abide by in order to deserve paradise.

Now, we commonly look at Islam from a Western point of view, i.e. through Christian or formerly Christian glasses. As a consequence, we look for things that could be the equivalent of what we know or experience in Christianity. When they are not there in Islam, we take up some that are and recast them in Western terms. We furthermore identify what really is extant according to our own standards. In particular the Western student of Islam constantly has to struggle against a temptation to reduce Islam to what interests him or her and to look for the "essence" of Islam or for "true" Islam in what can be marginal. Many people are interested in Islamic philosophy or mysticism because they are interested in philosophy or mysticism tout court more than in real Islam. On the other hand, few scholars choose to concentrate on what constitutes the core of Islam, i.e. law. The paucity of studies that deal with this topic is accounted for, partly by the tediously technical character of such studies, especially for Western people for whom the rulings of Islamic law do not obtain, and partly by the temptation that I have just been sketching.

We have to distinguish between what a Muslim may do and what he/she has to do; between what they actually do and what they should do; between the compulsory and the optional; between duty and hobby. Mysticism and philosophy are, at best, allowed. Obedience to the divine Law is compulsory and can be enforced.

Sociology simply does not want to look at things that way and, for reasons of method, does not distinguish between what people do and what they should do according to their own principles. Well now, on this point at least, sociologists may go and boil their head.

\section{The centrality of Law}

Law is not only a discipline among other ones in the spectrum of Islamic pursuits. It is the discipline of disciplines. It is the instance that distinguishes what is to be done and avoided. It distinguishes the right from the wrong in the case of areas of knowl- 
edge, too. It is competent on its own competence. A good example is Averroes' (too) famous Decisive Treatise, in which he deals as a legal scholar with the question of whether philosophy has to be compulsory, forbidden, encouraged, etc ${ }^{13}$. Basically, the work is a legal answer (fatwa) issued by the highest legal authority of the Almohad dynasty, the Great Qadi of Cordoba in person. Averroes as a highly competent professional issues a ruling on the activity that the same Averroes pursued in his leisure hours, as an amateur. To be sure, little wonder that Averroes1 should authorize and even condone as a duty what Averroes2 does. But the power to decide belongs to Averroes1, not to Averroes2.

As for mysticism, it had to worm its way into Islam to which it did not originally belong. There is no trace of it in the earlier historians. It was originally suspicious, and remained so till a relatively recent date, nay is still frowned upon in some circles. In order to gain acceptance and to find its way into mainstream Islam, it had to water down some of its claims. This happened in the $11^{\text {th }}$ century, i.e. long ago, to be sure, from our point of view, but more than four centuries after the rise of Islam. Sufism had to show that it enhanced the scrupulous practice of the law by supplementing it with inner life and devotion. Al-Ghazali was among the main artisans of this synthesis. It required a new interpretation of the idea of "intention". The word (niyya) originally designated a verbal declaration that one meant to accomplish a definite ritual action, so that the performer could not be understood to act haphazardly and to perform accidentally what the law requires. Later on, it went to designate the inner disposition of the "heart" that commands and orientates the "limbs" that perform visible actions.

Philosophy remained a marginal activity in the Islamic world ${ }^{14}$. It produced men of great genius and great achievements in various domains: logics with Farabi, metaphysics with Avicenna, careful exegesis of Aristotle with Averroes, et al. Their work deeply influenced Western thinkers. But socially they remained amateurs, people who had a job (music in the case of Farabi, medicine in the case of Avicenna, law in the case of Averroes) and indulged in their hobby after their day's work. This increases their personal merit. But philosophy never became a social institution.

This took place only in Europe, with the Universities. Each student who wanted to launch into the career of a physician, a lawyer or a theologian, first had to go though several years of "liberal arts" among which there were big chunks of philosophy. Every theologian is first a trained philosopher. He has to be one: study of philosophy is compulsory for theologians. On the other hand, one can be a perfectly competent faqih or, for that matter, rabbi, without having studied a whit of philosophy.

This is more than a fact of social and/or cultural history. We already are in the heart of the matter, since the basic concept of the philosophical enterprise, the concept

13 Averroes, Decisive Treatise, tr. C. Butterworth, Provo: Brigham Young University Press 2002.

14 This paragraph summarizes some passages from my The Legend of the Middle Ages. Philosophical Explorations of Medieval Christianity, Judaism, and Islam, tr. L. Cochrane, Chicago: The University of Chicago Press 2009 [here: Legend], especially p. 49-50. 
on which it is grounded is the concept of nature. Things are supposed to possess a stable nature that can be grasped and expressed in concepts.

Let us now turn to this concept of nature, first in Greece and in the Bible, then in Islam. For, in order to have a natural law, you must first have in your intellectual toolbox the adjective "natural", hence, basically, the concept of nature.

\section{Nature: "Athens" and "Jerusalem"}

You have this concept in Greece, particularly but not exclusively, among philosophers. Aristotle, the main philosophical authority for Islamic and Jewish philosophers as well as for Scholastic theologians, furnishes us with a full-fledged definition of "nature" in his Physics ${ }^{15}$. Moreover, he has a concept of the natural right. He distinguishes what is just (dikaion) according to nature and what is so because of some arbitrary convention ${ }^{16}$.

Interestingly for our purpose, the sources of Aristotle's thought are far older than his own concept of nature, but hail back to two big discussions. The first one took place among poets about the respective part played by natural endowment and training in the achievements of athletes: phyè vs. meletè. The second one was fought between Sophists and/or philosophers on the origin of laws, natural or conventional: physis vs. nomos ${ }^{17}$. And this is what interests us here.

Is the concept of nature present in the Bible?

In the New Testament the answer is definitely yes. Early Christianity took over the Greek concept of nature in the framework of a discussion on the validity of Moses' law. Paul asks: How is it that there are "decent" pagans, who are ignorant of the Torah? Moses' Law can't possibly be the only source of moral judgment. There must be something like "nature" (physis), like "conscience" (syneidessis). This is what Paul contends (Romans, 2, 15). Noble Pagans do by following their nature and obeying their conscience the same good works than Jews do because they abide by Moses' law.

As for the Old Testament, the question is trickier. It certainly does not contain the Hebrew word for "nature", tèva". It is not found earlier than the Mishnah, which was put together in the $2^{\text {nd }}$ century. In general, the Old Testament does not contain concepts, but rather stories. Nevertheless, if the word is lacking, the idea may be there, expressed in the biblical way, that is, through stories. Let me give some examples:

(a) In the first account of Creation at the beginning of Genesis, God creates plants that contain their seed that produce their fruit that contains their seed according to their species $(m \bar{i} n)$, in a constant cycle (le-min + suffix) (Genesis, $1,11.12(2 x) .21 .24 .25)$.

(b) The same idea is expressed by the story about God's resting after the six days work (Genesis, 2, 1-2). Of course, He does not need to take a nap because He is tired.

15 Aristotle, Physics, II, 1.

16 Aristotle, Nicomachean Ethics, V, VII (10), 1134b18-1135a15.

17 See F. Heinimann, Nomos und Physis. Herkunft und Bedeutung einer Antithese im griechischen Denken des 5. Jahrhunderts [1945], Darmstadt: Wissenschaftliche Buchgesellschaft 1972. 
But he leaves Creation to develop according to its own logic. The biblical author suggests this by indulging in a deep pun on the "they were completed" (wayekhullu) said of the heavens and the earth on the one hand and God's "He rested" (wayekhol) on the other one.

(c) Again, after the Flood, God swears that he will not destroy life again. The cycle of sowing and harvest will go on indefinitely (Genesis, 8, 22).

(d) Finally, in Isaiah's parable of the vineyard, God does not have to command His vine to produce grapes, and not, say, bananas. He simply expects it spontaneously to produce its fruit (Isaiah, 5, 2c .4b) ${ }^{18}$.

\section{Islam and the idea of nature}

Islam does not feel easy about the idea of nature.

The Quran has a tendency to attribute directly to God whatever happens in the world, not only what he created in the beginning, but what is still taking place. God lets rain fall so that grass can grow, etc. To be sure, analogous utterances are to be found in the Bible.

"Nature" is not a concept that Muslim thinkers willingly use. The philosophers who remain in the wake of Aristotle are a notable exception, but they never influenced the Islamic world-view deeply and permanently. Mainstream Islam fears that nature should be considered as some sort of rival deity. As is well known, "association" (širk), worshipping besides the only God other beings, is the only unforgettable sin in Islam. This has led some extreme Mutakallimūn to say that whoever speaks of nature as being the cause of a state of affairs is a polytheist. God is supposed to act directly and to create whatever takes place in the world: things, events, and even volitions in the hearts of men.

Causality came under fire with the thinkers of the Islamic school of apologetics (Kalam) and with Ghazali. In the Kalam, after the Mu'tazilites were defeated in 861, thinkers of the Ash arite school seized the intellectual power and kept it almost until our own day. According to them, things are loose bundles of properties. God simply has the habit (' $\bar{a} d a h)$ of joining together some of those properties when creating afresh at each instant a certain thing. Butter is yellow, melts easily, etc., whereas iron is hard and black, etc. not because there is a nature of butter and of iron, but because God, by and large, associates these properties in them ${ }^{19}$.

Philosophers accept the idea of nature more willingly than people of the Kalam. Nevertheless, when they find the idea of a natural law in their Greek source, they water it down, or shirk it. So do Farabi and Averroes when commenting upon Aristotle ${ }^{20}$.

18 More on this in my On the God of the Christians and one or two others, tr. P. Seaton, South Bend: Saint Augustine's Press 2013, p. 124.

19 See S. Pines, Studies on Islamic Atomism, tr. M. Schwarz, ed. T. Langermann, Jerusalem, Magnes Press, 1997; H. A. Wolfson, The Philosophy of the Kalâm, Cambridge, Harvard University Press, 1976.

20 See Law, p. 160-161. 


\section{An innate Law}

Whereas nature is not named in the Quran, we find there the idea that religion is natural to mankind, and in particular Islam is some sort of spontaneous, innate religion of every human being. This is expressed by the rather obscure word fitra ${ }^{21}$.

Muslims often call their religion by the name of religion of the fitra. This rests on a verse from the Quran: "So set thy purpose (O Muhammad) for religion as a man by nature upright - the nature (fitra) (framed) of Allah, in which He hath created man. There is no altering (the laws of) Allah's creation. That is the right religion, but most men know not" (Quran XXX, 30).

A famous declaration (hadith) put into the mouth of Muhammad casts some light on the concept of fitra: "Narrated Abu Huraira: Allâh's Messenger said, 'Every child is born on Al-Fitrah but his parents convert him to Judaism, Christianity or a Fireworshipper, as an animal delivers a perfect baby animal. Do you find it mutilated?' (Ma min mawlūd yulad ilā yulad 'alā l-fiţra, fa abawā-hu yuhawwidāni-hi aw yunaşşirānihi aw yumăğğisāni-hi, kamā tantiğu al-bahìma bahìma ğam 'à' a; hal tahissūna fìhā min $\breve{g} a d^{\prime} \bar{a} ' a$ ). Then Abu Huraira recited the holy Verses 30:30"22.

Interestingly, non-Muslims are compared with mutilated animals. Unbelievers do not fully meet the requirements of humanity. This tallies with what the Quran contends: they are like animals, nay worse than animals (Quran, VIII, 22) ${ }^{23}$. This is an almost necessary consequence of the idea that obedience to God's will, such as it is contained in His Law, is the only factor that makes man authentically human. Little wonder that in Judaism, too, pagans are sometimes said not fully to partake in humanity24.

Conversely, according to law books, a foundling is supposed to be Muslim as long as parents belonging to another religion do not claim him.

Furthermore, the Quran introduces a scene in which Islam is supposed to be rooted in a stage that is far earlier than the actual existence of human beings: "And (remember) when thy Lord brought forth from the Children of Adam, from their reins, their seed, and made them testify of themselves, (saying): Am I not your Lord? They said: Yea, verily. We testify. (That was) lest ye should say at the Day of Resurrection: Lo! of this we were unaware" (Quran, VII, 172).

The content of the scene may have been borrowed from some Jewish Midrash, which contains something analogous 25 . Be that as it may, there is, or was a point in time (or before it) in which all generations were there together. They are contemporaneous in front of the eternal God. The salient point is that the answer of mankind is

21 See G. Gobillot, La Conception originelle, ses interprétations et fonctions chez les penseurs musulmans (Cahiers des Annales Islamologiques, 18), Cairo : IFAO 2000.

22 Bukhari, Sahih, Volume 8, Book 77 (Qadar), §597, in: A. J. Wensinck, Concordance et indices des Traditions Musulmanes, Leiden 1933-, vol. 5, 179b-180b.

23 See Law, p. 80.

24 See bBaba Metsia, 114b, bYebamot, 61a and Maimonides, quoted in Legend..., p. 113-114.

25 See Midrash Tanhuma, Wayyigash, quoted in H. Speyer, Biblische Erzählungen im Qoran, Hildesheim: Olms 1961, p. 304-305. 
supposed to have been given before history began and to still hold good today. Each and every man has acknowledged God as his only lord, i.e. has professed Islam. As a consequence, each non-Muslim who lived and is still living has to be considered as an apostate from this primitive religion.

\section{Law: its realm}

Law for Islam is first and foremost an inseparably moral and religious evaluation of human actions. They fall into to five categories (ahkām): mandatory, recommended but not mandatory, neutral, advised against but not forbidden, forbidden. What is mandatory is rewarded, what is forbidden is punished. What is recommended is praised, but not rewarded; what is advised against is frowned upon, but not punished.

In principle, there is no separate moral or religious realm. Nevertheless, there used to be, in the Middle Ages, some sort of independent ethics, in the wake of the Greek and Persian ethical tradition. Such was the content of the treatises on the "refinement of mores" (tahdhīb al-akhlāq) written by Christians such as Yahya Ibn Adi or by Muslims, the most famous one among the latter being Ibn Miskawayh ${ }^{26}$.

The whole realm of what human beings can do (praxis), in contradistinction to what they can make (poiessis) is called by Aristotle, the medieval thinkers, and still by Kant (in a modified meaning) "practical". It encompasses three ways of governing (tadbir): governance of the individual, i.e. ethics, governance of the household, i.e. "economy", governance of the city, i.e. politics. Now, according to Islam, the whole realm of the practical, whatever a human being can do, is submitted to the claims of the divine.

There is no human action the quality of which is left out of the ken of divine legislation. Some authors, for instance al-Ghazali, even contend that neutral actions (rubbing one's chin, twiddling one's thumbs, etc.) are not just so; they have to be said to be such by an explicit declaration of the $\mathrm{Law}^{27}$.

\section{Law: its divine origin}

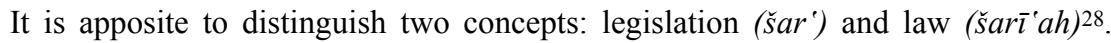
The second word is well-known to the Western audience. It designates the concrete result of the legislative activity: a legal system such as it arises from the interplay of several factors that have to be compounded with each other. The first one designates the fact that God decides to provide mankind with rules of conduct. Western historians

\footnotetext{
${ }^{26}$ Miskawayh, The Refinement of Character, tr. Constantine K. Zurayk, Beirut: American University 1968 .

27 Al-Ghazali, Al-Mustafā min 'ilm al-usūl, ed. I. M. Ramadân, Beirut: Dar al-Arqam, s.d., t. 1, p.

28 Wilfred Cantwell Smith, The Concept of Shari'a among some Mutakallimun, in: G. Makdisi (ed.), Arabic and Islamic Studies in Honor of H. A. R. Gibb, Cambridge, Mass.: Harvard University Press 1965, 581-602.
} 192. 
look for the origin of Islamic Law in merely human phenomena, for instance customs of ancient Arabia, remnants of the legal systems that obtained in the Near East, elements of Roman provincial law that were later ascribed to the Prophet, etc ${ }^{29}$. But for mainstream Islamic thinkers, at least since the $12^{\text {th }}$ century, those rules are the content of Islamic revelation.

Its object is not God's nature, not even His mores, but His will. God remains hidden behind a thick veil. I did not say "mysterious", for the Christian God too is mysterious. Christians see Him as a person, or more personal still than human persons. As a consequence, $\mathrm{He}$ is as mysterious as any person whose free decisions cannot be fully understood, let alone foreseen.

According to Islam, the only legitimate legislator is God. He alone can reward and punish seriously, i.e. eternally. Human rulings are hardly more than rules of thumb made necessary by the arising of some concrete problem for which no guidelines can be found in Revelation. No human ruling can stand in front of God's Word.

Now, God spoke through two channels.

First, he spoke directly in the Quran. The Quran is the word of God literally speaking. It was not inspired like the Christian Bible, but dictated to the Prophet. The "author" of the Quran is God in the same way as Milton was the author of Paradise Lost, even if he had to dictate it to his daughters, after he became blind. Muhammad is as little the author of the Quran as were Milton's daughters.

There is a second source, which is the very person of the Prophet. He is supposed to have been "purified" - this is the meaning of the epithet mustafa', that became a popular first name for male children. Muhammad was preserved ( $m a$ 'süm) from sin and error. As a consequence, he is, according to the Quran, "the beautiful example" (aluswa al-hasana) that can be imitated (Quran, XXXIII, 21). To be sure, imitating his behaviour is compulsory up to a point only, since the hadiths that tell us about what he did did not reach us through equally reliable channels, hence do not possess the same degree of certainty and cogency.

The Prophet even had some privileges that held good for him only and ceased with his demise, for instance marrying as many women as he wanted (Quran, XXXIII, 50). But what He did cannot be utterly wrong.

\section{Law: consequences of its divine origin}

\section{1) Reason}

Reason is a concept that should be made use of with caution. Many people attack Islam because it is believed to be "irrational". But, to the contrary, Islamic apologetics frequently points out that Islam is a rational religion, that does not require from us any "sacrifice of the intellect" (to take up the common misunderstanding on this phrase). It

29 Those scholars move in the wake of the path-breaking work of J. Schacht, The Origins of Muhammadan Jurisprudence, Oxford: Clarendon Press 1950 
does not contain commands the reasons for which are not accessible to the unaided human mind, unlike some huqqim in Judaism. In any case, it is more rational than Christianity that would like us to believe unbelievable things: three Gods, a God that changed into a man, bread that turns into human flesh, etc. Christianity is full of "mysteries" (once again, according to the popular misunderstanding of this concept), Islam is free from any.

Reason is a useful tool. As for religion, the Quran is full of injunctions in which the divine Speaker praises and recommends the use of intelligence ('aql). Through its use, man should be able to grasp the existence of a powerful and benevolent Creator ${ }^{30}$. The verses in which reason receives from God Himself the highest legitimization are constantly harped upon by scholars who interpret them in different senses. Some early mystics consider reason as being hardly more than the ability to understand that it is in our interest to obey God's commands and that disobedience would be foolish ${ }^{31}$.

As for the concrete history of Islamic civilization, Muslims wielded reason with as much dexterity as other people, so that scholars who lived in the Islamic world made considerable advances in many fields, for instance in mathematics (including astronomy) and other "profane" sciences ${ }^{32}$.

But on the other hand, unaided human reason cannot possibly be the source of legal obligation. Al-Shafi $i$, the leading figure of an influential legal school (madhab) even contended that whoever judges by himself is objectively a polytheist ${ }^{33}$. Reason can help us to find what is right whenever there is no authorized text. When there is one, reason has to submit and to content itself with the subordinate role of deducing from the divine ruling a whole range of applications. An extreme position is Ibn Khaldun's. For the Tunisian historian, "The intellect has nothing to do with the religious law and its views" (fa-inna al-'aql ma'zūl min al-šar' wa-anẓārihi) ${ }^{34}$.

\section{2) Interpretation}

Interpretation has a special meaning in Islam. In the West, the idea of interpretation has its roots in the legal realm, where Western law admits of a judgment of equity.

30 See my The Wisdom of the World. The Human Experience of the Universe in Western Thought, tr. T. Fagan, Chicago: The University of Chicago Press 2003, p. 58-59.

31 See Y. de Crussol, Rôle de la raison dans la réflexion éthique d'al-Muhāsibi ; Aql et conversion chez al-Muḥāsibi (165-243 / 782-857), Paris: Consep 2002.

32 For an overview, see R. Morelon and R. Rashed (ed.), Encyclopedia of the History of Arabic Science, London \& New York: Routledge 1996, 3 vol.

33 See Law, p. 167.

34 Ibn Khaldun, Prolégomènes d'Ebn Khaldoun, ed. E. Quatremère, Paris: Duprat 1858, t. 3, p. 122, 11-12; tr. F. Rosenthal, The Muqaddimah. An Introduction to History, New York: Pantheon books 1958 , t. 3, p. 154. The recent French translation is curiously ponderous: "La raison est située en un espace distinct de celui de la loi religieuse et de ses vues", Le livre des exemples, I. tr. A. Cheddadi, Paris : Gallimard 2002, p. 970. 
Aristotle already gives us a full theory under the name of epieikeia ${ }^{35}$. A law cannot foresee each and every case and has to rule in a rough way. When an injustice would arise from the strict application of the letter of the law (summum jus, summa injuria), the judge has to reason uphill from the wording of the law to its spirit, i.e. to the intention of the legislator. He must ask: what did the legislator want to prevent? If what he aimed at can be get by different means, that avoid blatant injustice, all the better.

In Islam, the Quran is believed to be not human in origin, but, literally speaking, God's Word, not inspired to a messenger, but dictated. Now, if God is the author of a text, no interpretation is possible if this should mean understanding God's intentions.

One example may suffice, since it was heavily discussed, especially in my native France. The command to the women of having to put head-gear (a veil) is twice in the Quran (XXIV, 31 and XXXIII, 59); but it is black on white in St. Paul, too (1 Corinthians 11,3-16). The content of the injunction is very much the same. But their sources are utterly different. When St. Paul expresses his wish that women should wear something on their hair when praying, he speaks like a man of flesh and blood who lived in the $1^{\text {st }}$ century in the Near East. His utterances can be interpreted to mean, generally speaking, that women should be clad modestly, according to habits that depend on time, place and fashion.

But in the Quran, God in person is supposed to speak. Now, He is not in space and time, He is eternal and omniscient. He knows his things and chose His words properly. Interpretation cannot possibly be the overbearing claim to know better than God what God wanted to convey. As a consequence, "interpreting" can only mean giving the words their exact weight. In this case, what is at stake is not the veil in itself, but, say, its length, its opacity, etc.

\section{3) No common ground between believers and unbelievers}

A consequence of the absence of the idea of a natural law is that, in principle at least, there are no common rules for the Muslims and the "unbelievers". To be sure, there are, because there must be, ways to solve concrete problems of coexistence and to exchange goods or prisoners with each other. For example, ambassadors from nonMuslim countries had to receive a warrant for their safety (aman), etc.

On the level of principles, however, the absence of a common ground in natural law has consequences. Let me give two examples of them:

a) Al-Ghazali (d. 1111) has a chapter on the command of the good and prohibition of the evil (al-amr bi 'l-ma'rüf wa l-nahì 'an 'il-munkar), an idea that originates in the Quran: "You are the best community, you command the right and prohibit the wrong" (III, 106-110), a formula that is in itself interesting. He discusses among, several ques- 
tions, who is allowed to exert this command and this prohibition ${ }^{36}$. He selects the example of fornication (sexual intercourse between unmarried grown-ups) as the least serious of all sexual sins. Now, Ghazali teaches: A non-Muslim living under Islamic rule, a Jewish or Christian dhimmi, is not allowed to prevent a Muslim from doing wrong by force. He hardly could, anyway, since he is not allowed to carry weapons. But supposing he could by mere brachial force, this would amount to exercising power over him. Now, Muslims are to wield the power over non-Muslims, not the other way round. What is still more interesting is that the non-Muslim is not even allowed verbally to remind a Muslim of what he should do or leave alone. The reason is that this would amount to display a pretension to authority over him, which would be a humiliation for him. Now, an unbeliever is far more worthy of humiliation than a Muslim, even a sinner.

b) Since law originates in God's commands, there is no way for people who adhere to the true religion of God, viz. Islam, to acknowledge the legitimacy of the rights of unbelievers. By this token, their properties do not really belong to them. They are unable to use them in an honest and proper way. As a consequence, it is a duty to deprive them of a good that they neither rightly possess nor exploit to the real advantage of mankind.

Al-Mawardi (d. 1058), in his treatise on Islamic leadership, quotes a hadith according to which Islamic soil makes what is in it forbidden, whereas the soil of "Associators" (dar al-shirk) makes what is in it authorized ${ }^{37}$. This means that whatever belongs to people who worship alongside Allah other divine beings (including the Christians) are free booty for the Muslims.

His contemporary, the philosopher Avicenna (d. 1037) expresses the reason for that in his description of the Just City: "such property and women (furüj, litt. vulvae) are not administered (mudabbarah) according to the constitution of the virtuous city, they will not bring about the good for which property and women are sought. Rather, they would contribute to corruption and evil" 38 .

Three centuries after them, Ibn Taymiyya, now the leading authority for Wahhabite Islam, an author who hardly pampers the philosopher when he attacks the "Logicians", agrees with him on this point ${ }^{39}$.

36 Ghazali, Ihyā 'Ulūm ad-Dīn, II, 9, §2, Beirut: Dar alkotob al-ilmiyah 1996, vo. 2, p. 342; see M. Cook, Commanding Right and Forbidding Wrong in Islamic Thought, Cambridge: Cambridge University Press 2000, p. 429-430.

37 Al-Mawardi, Al-Ahkām al-sultāniyya wa-'l-wilāyāt al-dīniyya, V, 2, Beirut: Dar al-kotob alilmiyya s.d., p. 76.

38 Avicenna, The Metaphysics of The Healing, X, 5 (7), tr. M. E. Marmura, Provo: Brigham Young University Press 2005, p. 376. See Legend...p. 136.

39 H. Laoust, Le Traité de droit public d'Ibn Taymiyya. Traduction annotée de la Siyāsa shar'iya, Damas : Institut français 1948, p. 35-36; on the larger context, see A. Morabia, Le Gihad dans l'Islam médiéval. Le « combat sacré » des origines au XII ${ }^{\mathrm{e}}$ siècle, Paris: Albin Michel, 1993, p. 246 ; see too p. $231,237-238$. 
It is interesting to compare the position of those authors with the one of Thomas Aquinas, who grants non-Christians (infideles), at least in some cases, the right to exercise power over the faithful ${ }^{40}$.

\section{Conclusion}

As a conclusion, I would like to draw a chart of sorts in which three complexes of legal ideas will take place. There is first the classical idea of natural law, that is, law grounded on human reason and conscience, such as it is defended in Greek philosophy, from Aristotle to the Stoics, and later on in Medieval Christian thought. Second, there is legal positivism, defended in modern Europe from Thomas Hobbes to Hans Kelsen and contemporary scholars. Third, there is Islamic legal thought.

Now, the three corners of this triangle, although they are worlds apart on some points, agree on some basic assumptions, even if this agreement may sound paradoxical, and does.

Natural law and legal positivism disagree on the origin of norms, but are in basic agreement as to their content. This content constitutes the "great platitudes" (C. S. Lewis), the elementary rules of decency, the survival kit of mankind, to which neither the former nor the latter add specific rulings, especially in the realm of cultic acts.

Natural law and Islam agree on the ultimate origin of Law, which is divine Law. Hence I could venture the paradox according to which both Christians and Muslims live in a theocracy, for the ultimate authority is and remains God's ${ }^{41}$. But the way in which God issues commands is not the same. In Islam, God's Word is first the Book, and secondly the Messenger. In Christianity, God speaks in human conscience.

Legal positivism and Islam agree ex negativo in their common rejection of a natural law. Contemporary, post-Christian legal scholars in the West share with Islamic doctors the tenet that law originates in a decision, so that there is only positive law. They disagree on the nature of the legislator: for Islam, it is the eternal omniscient and omnipotent God, for legal positivism it is unaided human reason, no longer understood as the image of the divine Word (Logos), but in a merely secular way. One may ask whether, in the long run, the latter will be able to hold its ground against the former.

40 Thomas Aquinas, Summa Theologica, IIaIIae, q. 10, a 10.

41 See my Are Non Theocratic Regimes Possible?, in: The Intercollegiate Review, 41-1, 2006, p. 3 12. 